
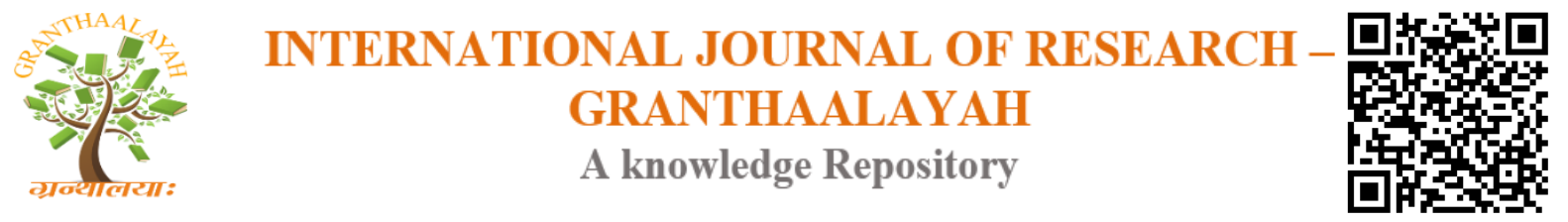

Science

\title{
PROSPECTIVE CLINICAL STUDY TO ASSESS THE SAFETY AND EFFICACY OF DRAVANTI BEEJ LEPA (LOCAL APPLICATION OF CROTON TIGLIUM) IN INDRALUPTA W. S. R. TO ALOPECIA AREATA
}

\author{
Dr. Aprana Pankaj Thapliyal ${ }^{1}$, Dr. Kalpana Denge ${ }^{2}$ \\ 1 MD Scholar, Department of Agadtantra, Dr. D Y Patil College of Ayurved and Research \\ Institute Nerul, Navi Mumbai, Maharashtra. - 400706, India \\ 2 Professor, Department of Agadtantra, Dr. D Y Patil College of Ayurved and Research Institute \\ Nerul, Navi Mumbai, Maharashtra. - 400706, India
}

\begin{abstract}
Indralupta (Alopecia Areata) is not life threatening disorder but it definitely affects the quality of life like impairing psychological well-being thus affecting mental and social status of person due to bald patch. It is characterized by smooth, circumscribed bald patch on the hair bearing area. The risk of allopathic treatment outweighs their benefits. Indralupta is considered under Kshudraroga by most of the authors of classical Ayurvedic texts. Safety and efficacy of Dravanti beeja lepa in regeneration of hair in Indralupta is assessed through present study. Prospective open randomized single-arm clinical trial was carried out on 30 patients showing classical symptoms of Indralupta. A Skin patch test has been done prior to apply the lepa for safety assessment. The Dravanti beeja lepa was given for local application twice a day over a period of 28 day. Indralupta was found to be more prevelant in males. Intake of Amla, Katu and lavana Rasa, non-vegetarian diet, stress factor and use of cosmetics could be considered as etiological factor of Indralupta. On regular use of Dravanti beeja lepa, regeneration of hair was also observed to significant level. Thus, Dravanti beeja lepa proved its safety and efficacy for topical application.
\end{abstract}

Keywords: Alopecia Areata; Indralupta; Dravanti Beej Lepa.

Cite This Article: Dr. Aprana Pankaj Thapliyal, and Dr. Kalpana Denge. (2018). "PROSPECTIVE CLINICAL STUDY TO ASSESS THE SAFETY AND EFFICACY OF DRAVANTI BEEJ LEPA (LOCAL APPLICATION OF CROTON TIGLIUM) IN INDRALUPTA W. S. R. TO ALOPECIA AREATA." International Journal of Research - Granthaalayah, 6(7), 185-190. https://doi.org/10.29121/granthaalayah.v6.i7.2018.1297.

\section{Introduction}

Hair form an important anatomical structure of the body, derived from ectoderm of skin, which not only have protective function but also adds beauty to the face. Hair is made up of protein called keratin produced in hair follicles in the outer layer of skin. As follicles produce new hair cells, old cells are being pushed out through the surface of the skin at the rate of about six inches a year. The 
hair is actually a string of dead keratin cells. As hairs originate from the epidermis during embryological development, they are also known as epidermal derivatives. An average adult head has about $1,00,00$ to $1,50,00$ hairs and loses upto 100 of them a day. ${ }^{1}$

Hair loss (Alopecia) has a devastating effect on the patient's quality of life and selfesteem.Alopecia is essentially a cosmetic disorder. Alopecia Areata (AA) is a common form of non- scarring alopecia involving the scalp and/ or body, characterized by hair loss without any clinical inflammatory signs. It is one of the most common forms of hair loss seen by dermatologists and accounts for $25 \%$ of all the alopecia cases. ${ }^{2}$ It was first described by Cornelius Celsus, and the term AA was coined by Sauvages in $1760 .{ }^{3}$ It accounts for 2-3\% of the new dermatology cases in UK and USA, 3.8\% in China, and $0.7 \%$ in India. ${ }^{3-5}$ In Ayurveda, hair problem described under the broad heading of KshudraRoga ${ }^{6}$, Kapala Rogas $^{7}$ as Khalitya, Palitya, Indralupta. loss of hair in form of patches in some scalp area by the vitiation of tridosha and raktadhatu term as 'Indralupta'. Acharya Sushruta, the Father of Surgery, has preferred upakrama like application of 'lepa' etc, in some cases thus avoiding surgery. 'Indralupta' (Alopecia) is one such disorder where lepa has been advocated. ${ }^{8}$

Dravanti beeja has been chosen as a trial drug for lepa application as according to Vriddha Vaidya Parampara the external application of Icchabhedi Rasa and Dravanti beeja are used to treat Indralupta ${ }^{9}$ Dravanti (Croton tiglium) is a plant irritant poison. ${ }^{10}$ It is an Upavisha-according to Charak Samhita ${ }^{11}$ a potent poison if used in a proper way and does may act as a medicine. To assess the safety of Dravanti beeja lepa a skin patch test ${ }^{12}$ has been done prior to apply and its efficacy was observed on patients of Indralupt (Alopecia).

\subsection{Need of Study}

Alopecia is one of the most common problem faced by people across all age groups.

One person in every four suffer from hair loss, the reason being in today's fast paced life marred by pollution, stress, unhealthy eating habits and moreover the genetic causes.

To identify an economical, non-surgical way to regrow and retain the hair with Dravanti Beej as the cost of allopathic treatment like hair transplant, use of steroid (Minoxidil) etc. are quite high and have side effects.

As Dravanti beej is irritant in nature, evaluation of its safety is essential.

To boost the self-confidence of individual and improve the quality of life.

\section{Aims and Objectives}

To explore the safety and efficacy of Dravanti Beej Lepa (Local Application of Croton tiglium) in Indralupta w.s.r. to Alopecia Areata through clinical study.

\section{Methodology}

- Drug-Dravanti Beej

- Type of study: Prospective Randomized Non-comparative (single group) clinical trial

- Sample Size: 30 patients 
- Place of study: The study was conducted at D.Y. Patil School of Ayurved Hospital Nerul, Navi Mumbai.

- DOSAGE SCHEDULE

1) Local application of purified Dravanti Beej Lepa twice in a day for four weeks. When the lepa dried was removed by wash with normal water.

2) Thickness of lepa: $1 / 4$ Anguli ( $2 \mathrm{~mm}$ ).

3) Follow ups were taken on day 7,14 and 28.

4) The cases of adverse effect of the drug were treated with local application of "ShatdhautGhrit" and "Narikel Tel".

\section{Inclusion Criteria}

1) Diagnosed patients of Indralupta (Alopecia areata) showing clinical finding as oval or round, well circumscribed, bald patch (not larger than $3 \mathrm{~cm}$ in diameter) with a smooth surface in a diffused distribution.

2) 30 patients of either sex in age group 18 to $60 \mathrm{yr}$.

\section{Exclusion Criteria}

1) Patients having more than one patches of Indralupta.

2) Patients having bald patches on beard or moustache-as these cases are rare. The uniformity of data would not have been maintained.

3) Patients having Khalitya, Alopecia totalis or Alopecia universalis.

4) Pregnancy \& Lactation.

5) Alopecia due to burns.

\section{Criteria for Assessment}

- Subjective Assess

No of patch, size of patch, Area covered by hair follicles (arbitrary \% improvement in hair)

\section{- Safety Assessment}

SKIN PATCH TEST prior to application of Lepa on scalp, for early detection of side effects (Itching, redness, irritation, inflammation).

A patch test is a method used to determine whether a specific substance causes allergic inflammation of a patient's skin. In this, drug will be applied on a small area of the patient's back or arm in a patch and will indicate any local allergic reaction on the small area of the patients back, where the drug were planted. Interpretation of result is as under:

1) Grade 1-Negative (-) - No skin reaction.

2) Grade 2-Mild positive (+) - Slightly elevated pink or red plaque.

3) Grade 3-Moderate positive (++) - Papulovesicles, itching.

4) Grade 4-Severe reaction (+++) - Severe redness and blisters.

Patients having severe reaction had been excluded from the study. However, no patient had any severe reaction during the study. 


\section{Observation}

Table 1:

\begin{tabular}{|l|l|l|}
\hline \multicolumn{3}{|c|}{ Age Wise Distribution } \\
\hline Age in years & No. OF Patients & Percent \\
\hline $18-28$ & 13 & $\mathbf{4 3 . 3 3 \%}$ \\
\hline $29-39$ & 13 & $\mathbf{4 3 . 3 3 \%}$ \\
\hline $40-50$ & 2 & $\mathbf{6 . 6 7 \%}$ \\
\hline $51-60$ & 2 & $\mathbf{6 . 6 7 \%}$ \\
\hline TOTAL & 30 & $\mathbf{1 0 0} \%$ \\
\hline
\end{tabular}

From the table 01 , we can see that maximum no of patients i.e. $43.33 \%$ were in age group 18-28 and 29-39. Minimum no of patients i.e. $6.67 \%$ were in age group 40-50 and 51-60 in the study.

Table 2:

\begin{tabular}{|l|l|l|}
\hline \multicolumn{3}{|c|}{ Sex Wise Distribution } \\
\hline Sex & No. OF Patients & Percent \\
\hline Male & 20 & $\mathbf{6 6 . 6 7 \%}$ \\
\hline Female & 10 & $\mathbf{3 3 . 3 3 \%}$ \\
\hline TOTAL & 30 & $\mathbf{1 0 0 \%}$ \\
\hline
\end{tabular}

From the table 02 above, it is noted that male were $66.67 \%$ and females were $33.33 \%$ in the study.

\subsection{Skin Patch Test}

Table 3:

\begin{tabular}{|l|l|l|}
\hline \multicolumn{3}{|c|}{ Skin Patch Test } \\
\hline Grade & No. Of Patients & Percentage \\
\hline Grade 1 & 6 & $20 \%$ \\
\hline Grade 2 & 13 & $43.33 \%$ \\
\hline Grade 3 & 11 & $36.67 \%$ \\
\hline Grade 4 & 0 & $0 \%$ \\
\hline Total & 30 & $100 \%$ \\
\hline
\end{tabular}

\subsection{Statistical Analysis to Assess Subjective Criteria Using Wilcoxon Test}

\begin{tabular}{|l|l|l|l|l|l|l|l|l|}
\hline Sr. No. & & & MEAN & SD & N & W & P & Result \\
\hline $\mathbf{1}$ & Size of patch & BT & 0.95 & 0.37 & 30 & 465 & $<0.0001$ & Highly significant \\
\hline & & AT & 0.34 & 0.14 & & & & \\
\hline & & DIFF & 0.61 & 0.30 & & & & \\
\hline
\end{tabular}

\section{Result}

From the above data,it is obsereved that in 30 patients of Indralupta, on day 28 i.e. at end of the study, average hair growth was $60 \%$ on bald patch. 
Thus average $60 \%$ improvement was seen in re-growth of hairs in the study period of 4 week.

\section{Discussion}

Indralupta is common in males and in the age group of 31-40 years. It occurs mainly in people with Vata- Pittaprakruti. Hormonal disturbance, emotional ups and downs are common in this (31-40) age group. Use of shampoo, color, hair conditioner, which are harmful to hair are frequent in this age group causing hair loss. Many patients had history of Indralupta from pitrajkula. These results indicate that Indralupt is a hereditary disease with Y- linked characters. Male pattern baldness sufferer inherits hair follicle which is genetically sensitive to Dihydrotesterone (DHT). Those who develop their first patch of Alopecia Areata before the age of thirty have a higher possibility that other family members will also have it. There was statistically significant reduction in numbers of patches and percentage loss of hair. Regrowth of hair was also observed to a significant level at the end of 28 days of treatment.

Out of 30, patients included in trial in which Dravanti beeja lepa was administered for 28 days, total $60 \%$ improvement was seen. In Indralupta, vata along with pitta vitiation that sheds off hair from the hair follicle and kaphadushti causes avarodh of the hair roots thereby obstructing new hair to grow. Dravanti has katu, tikta, bhedniya properties due to which, it removes obstruction of kapha pitta from the hair follicle and hence helps in new hair growth.

Thus, Dravanti beeja lepa proved its safety and efficacy for topical application.

\section{Conclusion}

The safety and efficacy of Dravanti Beej lepa is said to be proven, because of-

1) Significant hair growth on the patch of Indralupta

2) Non serious, mild, minimal side effects.

Indralupta was found to be more prevalent in males. Intake of Amla, Katu, Lavana Rasa, nonvegetarian diet, stress factor, and use of cosmetic could be considered as etiological factors of Indralupta. On regular use of Dravanti beej lepa, regeneration of hair was also observed to significant level and proved its safety and efficacy for topical application. Small sample size, single group, use of simple safety and efficacy parameter and short duration of study were the limitations of the present study. The same study can be carried out with oral medication, use of advanced efficacy parameters and with longer duration.

\section{References}

[1] Cash, T.F. The Psychology of hair loss and its implication for patient care. Clinical Dermatol 2001; 19: 161-166.

[2] McMichael AJ, Pearce DJ, Wasserman D, Camacho FT, Fleischer Jr AB, Feldman SR, et al. Alopecia in the United States: Outpatient utilization and common prescribing patterns. J Am AcadDermatol 2007; 57: S49-51.

[3] Sharma VK, Dawn G, Kumar B. Profile of alopecia areata in Northen India. Int J Dermatol, 1996; 35: $22-7$. 
[4] Safavi KH, Muller SA, Suman VJ, MoshellANtreaMelton LJ $3^{\text {rd }}$. Incidence of alopecia areata on Olmsted County, Minnesota, 1995; 70:628 33.

[5] Tan E, Tay YK, Goh CL, Chin Giam Y. The pattern of alopecia areata in Singapore_A study of 219 Asians. Int J Dermatol 2002; 41:748-53.

[6] Su.Ni-13/33-34 Page No-368 Book Name-SuśrutSamhitā Part-1 Author-Kaviraja Ambika DuttShastri, A.M.S, Publication-Chaukhamba Sanskrita Sansthan-Varanasi

[7] Ashtang Samgraha of Vagbhata,translated by Murthy K R, Varanasi, Chaukhamba, 2005, Uttartantra, chapter 27, pg no 21, verse no. 13.

[8] Sushrutsamhita by Maharshi Sushruta, Nibandhsamgraha commentary by Dalhanacharya, Edited by Yadavji T.,Varanasi, Chaukhamba, 2004, Chikitsasthana, Chapter 1, pg no 405, verse no. 101103.

[9] Chikitsa Prabhakar Kshudraroga, Aogle, P.B., Pune, Kala Sadhana Prakashan, 1986, pg no 673.

[10] Viz, K. Forensic Medicine and Toxicology. $6^{\text {th }}$ edition, Chapter 5, pg no 446. New Delhi- Elsevier India Pvt Limited.

[11] C.Su-1/126, Page No-49 Book Name-CarakSamhitā Part-1 Author-Sri SatyaNarayanaSastri, Publication- ChaukhambhaBharati Academy-Varanasi.

[12] Patchtest.org, interpreting patch test.

\footnotetext{
*Corresponding author.

E-mail address: aparna2531@gmail.com
} 